\title{
Combination therapy with silibinin, pegylated interferon and ribavirin in a patient with hepatitis $C$ virus genotype 3 reinfection after liver transplantation: a case report
}

\author{
Johanna Knapstein, Marcus A Wörns, Peter R Galle and Tim Zimmermann*
}

\begin{abstract}
Introduction: Hepatitis C virus reinfection occurs universally after liver transplantation with accelerated cirrhosis rates of up to $30 \%$ within 5 years after liver transplantation. Management of hepatitis C virus reinfection is complicated by drug interactions and pre-treatment. Dual antiviral therapy with pegylated interferon and ribavirin only reaches sustained virological response rates of approximately 30\% after liver transplantation. With the approval of the viral NS3/ $4 \mathrm{~A}$ protease and NS5B ribonucleic acid -dependent ribonucleic acid polymerase inhibitors, combination therapy offers new therapeutic options resulting in considerably higher sustained virological response rates in the non-transplant setting. However, silibinin has also shown potent antiviral activity in non-responders to dual therapy.
\end{abstract}

Case presentation: We report the first case of antiviral therapy with pegylated interferon and ribavirin in combination with silibinin post-liver transplantation in a 50-year-old Caucasian man with genotype 3 reinfection with prior non-response.

Silibinin was administered at a dose of $20 \mathrm{mg} / \mathrm{kg} /$ day intravenously for 2 weeks and continued orally for 47 weeks in

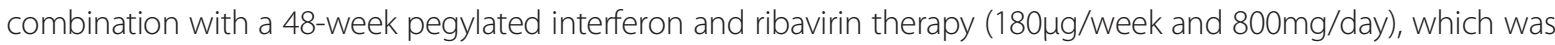
started on day 8. Pegylated interferon and ribavirin doses were adapted to 135 $\mu \mathrm{g} /$ week and 600 $\mathrm{mg} /$ day. After 4 weeks of therapy, the viral load declined $6 \log _{10}$ and became undetectable in week 6 , resulting in a sustained virological response 24 weeks after the end of therapy.

In general, antiviral therapy was well tolerated. Side effects included pruritus and anaemia leading to erythropoietin therapy.

Conclusions: Combination therapy with pegylated interferon, ribavirin and silibinin resulted in sustained virological response 24 weeks after the end of therapy in a patient reinfected with hepatitis C virus genotype 3 who was a prior non-responder after liver transplantation. Silibinin therapy may offer a new therapeutic option for patients reinfected with non-genotype 1 hepatitis C virus who have had a liver transplanted and are non-responders.

Keywords: Antiviral therapy, Liver transplantation, Silibinin

\footnotetext{
* Correspondence: tim.zimmermann@unimedizin-mainz.de

I. Department of Internal Medicine, Johannes Gutenberg-University, Langenbeckstraße 1, 55131 Mainz, Germany
} 


\section{Introduction}

Hepatitis C virus (HCV) reinfection occurs universally after liver transplantation (LT) [1]. Under immunosuppression, the time course of recurrent $\mathrm{HCV}$ is accelerated, with cirrhosis rates of up to $30 \%$ within 5 years of LT [2]. So far, antiviral therapy has been limited to a combination of pegylated interferon (peg-IFN) and ribavirin (RBV) with sustained virological response (SVR) rates of approximately $30 \%$ post-LT [3-5]. With the approval of the viral NS3/4A protease inhibitor (PI) simeprevir and NS5B ribonucleic acid (RNA)-dependent RNA polymerase inhibitor (RdRpI) sofosbuvir, combination therapy offers new therapeutic options resulting in considerably higher SVR rates of $66 \%$ and $75 \%$ in treatment-naïve patients infected with HCV genotype 1 in the non-transplant setting [6,7]. However, the management of $\mathrm{HCV}$ reinfection after LT is complicated by drug interactions, tolerability and pre-treatment $[8,9]$. Therefore an individual treatment regimen is often required. However, PI-based triple therapy is limited to patients infected with $\mathrm{HCV}$ genotype 1. To date, very few data exist on the treatment of recurrent non-genotype 1 $\mathrm{HCV}$-infection after LT.

As silibinin has been shown to be a potent antiviral agent in prior non-responders to dual therapy $[10,11]$, we present here the first case of antiviral therapy with pegIFN and RBV in combination with silibinin post-LT in a genotype 3 reinfected patient with prior non-response.

\section{Case presentation}

A 50-year-old Caucasian man underwent a liver transplant in 2008 due to hepatocellular carcinoma based on chronic HCV genotype 3a-associated liver cirrhosis. $\mathrm{HCV}$ was diagnosed in 1996. He was pre-treated with dual antiviral therapy pre-LT in 1997, resulting in primary non-response. In 2008, recurrent HCV was detected in liver biopsy. Therefore, he underwent a second attempt of dual antiviral therapy over 48 weeks, resulting in a relapse. He was referred to our LT out-patient clinic in a good state of general health (body mass index 26.2, $180 \mathrm{~cm}, 85 \mathrm{~kg}$ ) with a request for antiviral therapy. HCVRNA measured $14 \times 10^{6} \mathrm{IU} / \mathrm{mL}\left(\mathrm{COBAS}^{\odot} \mathrm{TaqMan}^{\circ} \mathrm{HCV}\right.$ test, version 2.0, Roche Diagnostics AG, Rotkreuz, Switzerland; lower limit of quantification: $25 \mathrm{IU} / \mathrm{mL}$; lower limit of detection: $10 \mathrm{IU} / \mathrm{mL}$ ). His serum transaminases were slightly elevated: alanine aminotransferase 103U/L, upper limit of normal (ULN <50IU/L; aspartate aminotransferase 114U/L, ULN 35IU/L). All other liver values were within the normal range (alkaline phosphatase, gamma-glutamyltransferase, bilirubin, international normalized ratio and albumin). Haemoglobin, leukocyte and thrombocyte counts were $16.6 \mathrm{mg} / \mathrm{dL}, 8.6 / \mathrm{nL}$ and $118 / \mathrm{nL}$, respectively (Figure 1). Side diagnoses included hypertension and diabetes mellitus type 2 .

As silibinin has shown potent antiviral activity in prior non-responders to dual therapy, informed consent was given for a triple combination therapy of silibinin, pegIFN and RBV. He was given tacrolimus $1 \mathrm{mg}$ twice a day (BID) and mycophenolate-mofetil 500mg BID for immunosuppression as well as co-medication with amlodipine $(5 \mathrm{mg} /$ day) and pantoprazole $(40 \mathrm{mg} /$ day); insulin injections were also continued. Silibinin was administered $20 \mathrm{mg} / \mathrm{kg} /$ day intravenously for 2 weeks and continued orally $560 \mathrm{mg} /$ day for 47 weeks in combination

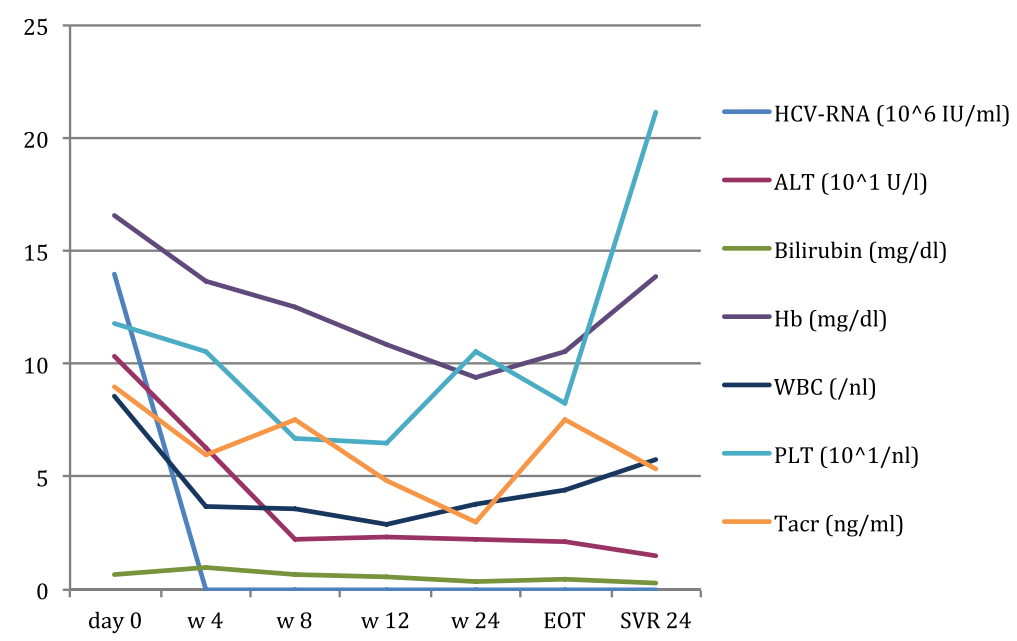

Figure 1 Course of hepatitis $C$ virus-ribonucleic acid $\left(10^{6} \mathrm{lU} / \mathrm{mL}\right)$, alanine aminotransferase $\left(10^{1} \mathrm{U} / \mathrm{L}\right)$, haemoglobin $(\mathrm{mg} / \mathrm{dL})$, white blood cells (cells $/ \mathrm{nL}$ ) and platelets $\left(10^{1} / \mathrm{nL}\right)$ during therapy. After 4 weeks of therapy, viral load declined $6 \log _{10}$ and became negative in week 6 resulting in SVR 24. Side effects included pruritus and anaemia, leading to the application of erythropoietin. Abbreviations: ALT, alanine aminotransferase; EOT, end-of-treatment; Hb, haemoglobin; HCV-RNA, hepatitis C virus-ribonucleic acid; PLT, platelets; SVR, sustained virological response; Tacr, tacrolimus; w, week; WBC, white blood cells. 
with a 48-week peg-IFN and RBV therapy with $180 \mu \mathrm{g} /$ week and $800 \mathrm{mg} /$ day started on day 8. Peg-IFN and RBV doses were adapted to $135 \mu \mathrm{g} /$ week and $600 \mathrm{mg} /$ day. After 4 weeks of therapy, the viral load declined $6 \log _{10}$ and became undetectable in week 6, resulting in SVR 24. Therapy was well tolerated; side effects included dyspnoea, pruritus and anaemia, leading to the application of $250 \mathrm{mg}$

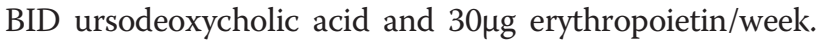
Red blood cell, leukocyte and platelet counts, as well as tacrolimus through levels, were checked once a week.

\section{Discussion}

Antiviral therapy of recurrent $\mathrm{HCV}$ after LT is an issue of high interest and the time course of fibrosis progression is accelerated under immunosuppression [2]. Improvements in antiviral therapy are urgently required as SVR rates for dual therapy in patients who are $\mathrm{HCV}$ positive after LT are low [3,4]. PI and RdRpI-based combination for antiviral therapy in non-LT cohorts leads to significantly higher SVR rates compared to a dual therapy [6-10]. However, the management of HCV post-LT is complicated by drug interactions, side effects and pretreatment $[11,12]$.

However, PI-based triple therapy is limited to patients infected with HCV genotype 1. To date, very few data exist on the therapy of recurrent non-genotype $1 \mathrm{HCV}$ infection after LT.

In vitro experiments have shown that HCV replication is significantly inhibited by silibinin [13]. Silibinin has a strong anti-oxidative effect [14]. This may improve the response to IFN in non-responders to dual therapy since oxidative stress leads to impaired IFN signalling [15]. However, evidence for beneficial effects in humans has been equivocal. Therefore, the efficacy and safety of highdose intravenous silibinin, followed by a lower dose oral application in combination with dual antiviral therapy, were evaluated by Ferenci et al. [16] in 2008 in chronic HCV genotype 1, 2 and 4 infected former non-responders. This study showed that silibinin is well tolerated and reveals a substantial antiviral effect against $\mathrm{HCV}$ in nonresponders [16]. A recent study reported similar results in the transplant setting for patients reinfected with $\mathrm{HCV}$ genotype 1 [17]. We present here the first case of successful antiviral treatment with silibinin in combination with peg-IFN and RBV in a patient reinfected with HCV genotype 3 after LT with prior non-response to dual therapy. Treatment with silibinin might result in an IFN-sensitising effect in IFN non-responders following LT.

\section{Conclusions}

Combination therapy of peg-IFN, RBV and silibinin resulted in SVR 24 in a patient who had a liver transplanted, who was reinfected with $\mathrm{HCV}$ genotype 3 and who was therapy naïve. Combination therapy with silibinin might be a useful approach for the therapy of recurrent nongenotype $1 \mathrm{HCV}$ infection after LT.

\section{Consent}

Written informed consent was obtained from the patient for publication of this case report and the accompanying images. A copy of the written consent is available for review by the Editor-in-Chief of this journal.

\begin{abstract}
Abbreviations
BID: Twice a day; HCV: Hepatitis C virus; LT: Liver transplantation; peg-IFN: Pegylated interferon; PI: Protease inhibitor; RBV: Ribavirin; RdRpl: RNA-dependent RNA polymerase inhibitor; RNA: Ribonucleic acid; SVR: Sustained virological response; ULN: Upper limit of normal.
\end{abstract}

\section{Competing interests}

The authors declare that they have no competing interests.

\section{Authors' contributions}

JK collected the data and drafted the manuscript. PRG, MAW and TZ conceived of the case, and participated in therapy design and coordination and helped to draft the manuscript. All authors read and approved the final manuscript.

\section{Acknowledgements}

The authors received lecture fees and travel grants from Roche, Janssen and MSD.

Received: 20 January 2014 Accepted: 11 June 2014

Published: 21 July 2014

\section{References}

1. Garcia-Retortillo M, Forns X, Feliu A, Moitinho E, Costa J, Navasa M, Rimola A, Rodes J: Hepatitis C virus kinetics during and immediately after liver transplantation. Hepatology 2002, 35:680-687.

2. Gane EJ: The natural history of recurrent hepatitis $C$ and what influences this. Liver Transp/ 2008, 14:36-44.

3. Berenguer M: Systematic review of the treatment of established recurrent hepatitis $C$ with pegylated interferon in combination with ribavirin. J Hepatol 2008, 49:274-287.

4. Wang CS, Ko HH, Yoshida EM, Marra CA, Richardson K: Interferon-based combination anti-viral therapy for hepatitis $C$ virus after liver transplantation: a review and quantitative analysis. Am J Transplant 2006, 6:1586-1599.

5. Xirouchakis E, Triantos C, Manousou P, Sigalas A, Calvaruso V, Corbani A, Leandro G, Patch D, Burroughs A: Pegylated interferon and ribavirin in liver transplant candidates and recipients with HCV cirrhosis: systematic review and meta-analysis of prospective controlled studies. J Viral Hepat 2008, 15:699-709.

6. Kwo PY, Lawitz EJ, McCone J, Schiff ER, Vierling JM, Pound D, Davis MN, Galati JS, Gordon SC, Ravendhran N, Rossaro L, Anderson FH, Jacobson IM, Rubin R, Koury K, Pedicone LD, Brass CA, Chaudhri E, Albrecht JK, SPRINT-1 investigators: Efficacy of boceprevir, an NS3 protease inhibitor, in combination with peg-interferon alpha- $2 b$ and ribavirin in treatment-naive patients with genotype 1 hepatitis C infection (SPRINT-1): an open-label, randomised, multicentre phase 2 trial. Lancet 2011, 376:705-716.

7. Jacobson IM, McHutchinson JG, Dusheiko G, Di Bisceglie AM, Reddy KR, Bzowej NH, Marcellin P, Muir AJ, Ferenci P, Flisiak R, George J, Rizzetto M, Shouval D, Sola R, Terg RA, Yoshida EM, Adda N, Bengtsson L, Sankoh AJ, Kieffer TL, George S, Kauffman RS, Zeuzem S, ADVANCE Study Team: Telaprevir for previously untreated chronic hepatitis $C$ virus infection. N Engl J Med 2011, 364:2405-2416.

8. Lawitz E, Mangia A, Wyles D, Rodriguez-Torres M, Hassanein T, Gordon SC, Schultz M, Davis MN, Kayali Z, Reddy KR, Jacobson IM, Kowdley KV, Nyberg L, Subramanian GM, Hyland RH, Arterburn S, Jiang D, McNally J, Brainard D, Symonds WT, McHutchison JG, Sheikh AM, Younossi Z, Gane EJ: Sofosbuvir for previously untreated chronic hepatitis C infection. N Engl J Med 2013, 368:1878-1887.

9. Jacobson IM, Dore GJ, Foster GR, Fried MW, Radu M, Rafalsky W, Moroz L, Craxi A, Peeters M, Lenz O, Ouwerkerk-Mahadevan S, De La Rosa G, 
Kalmeijer R, Scott J, Sinha R, Beumont-Mauviel M: Simeprevir with pegylated interferon alfa 2a plus ribavirin in treatment-naive patients with chronic hepatitis C virus genotype 1 infection (QUEST-1): a phase 3, randomised, double-blind, placebo-controlled trial. Lancet 2014, in press.

10. Manns M, Poordad F, de Araujo ES A: Simeprevir (TMC435) with peginterferon/ribavirin for treatment of chronic HCV genotype-1 infection in treatment-naïve patients: results from QUEST-2, a phase III trial. J Hepatol 2013, 58:568.

11. Terrault N: Liver transplantation in the setting of chronic HCV. Best Pract Res Clin Gastroenterol 2012, 26:531-548.

12. Kiser JJ, Burton JR, Anderson PL, Everson GT: Review and management of drug interactions with boceprevir and telaprevir. Hepatology 2012. 55:1620-1628.

13. Polyak SJ, Morishima C, Shuhart MC, Wang CC, Liu Y, Lee DY: Inhibition of T-cell inflammatory cytokines, hepatocyte NF-kappaB signalling, and HCV infection by standardised Silymarin. Gastroenterology 2007, 132:1925-1936.

14. Pietrangelo A, Borella F, Casalgrandi G, Montosi G, Ceccarelli D, Gallesi D, Giovannini F, Gasparetto A, Masini A: Antioxidant activity of silibinin in vivo during long-term iron overload in rats. Gastroenterology 1995, 109:1941-1949.

15. Di Bona D, Cippitelli M, Fionda C, Cammà C, Licata A, Santoni A, Craxì A: Oxidative stress inhibits IFN-induced antiviral gene expression by blocking the JAK-STAT pathway. J Hepatol 2006, 45:271-279.

16. Ferenci P, Scherzer TM, Kerschner H, Rutter K, Beinhardt S, Hofer H, Schöniger-Hekele M, Holzmann H, Steindl-Munda P: Silibinin is a potent antiviral agent in patients with chronic hepatitis $C$ not responding to pegylated interferon/ribavirin therapy. Gastroenterology 2008, 135:1561-1567.

17. Eurich D, Bahra M, Berg T, Boas-Knoop S, Biermer M, Neuhaus R, Neuhaus $P$, Neumann U: Treatment of hepatitis C-virus-reinfection after liver transplant with silibinin in non-responders to pegylated interferon-based therapy. Exp Clin Transplant 2011, 9:1-6.

doi:10.1186/1752-1947-8-257

Cite this article as: Knapstein et al:: Combination therapy with silibinin pegylated interferon and ribavirin in a patient with hepatitis $C$ virus genotype 3 reinfection after liver transplantation: a case report. Journal of Medical Case Reports 2014 8:257.

\section{Submit your next manuscript to BioMed Central and take full advantage of:}

- Convenient online submission

- Thorough peer review

- No space constraints or color figure charges

- Immediate publication on acceptance

- Inclusion in PubMed, CAS, Scopus and Google Scholar

- Research which is freely available for redistribution 